\title{
Schools' Feeding Programs and the Trade-off between Child Labor and Schooling: Evidence from BRIGHT
}

\section{Survey}

\author{
Sandrine Aïda Koissy-Kpein ${ }^{1, *}$ \\ ${ }^{1}$ Population et Emploi, CEPS/INSTEAD, Esch sur Alzette, Luxembourg \\ *Correspondence: Tel: 352-58-585-5405 E-mail: s.koissy-kpein@ceps.lu
}

Received: September 15, 2012 Accepted: July 17, 2013 Published: August 21, 2013

doi:10.5296/rae.v5i3.2386 URL: http://dx.doi.org/10.5296/rae.v5i3.2386

\begin{abstract}
The focus in this paper is on the role of educational programs (mainly feeding programs) on the eradication of child labor and the co-choice parents make between child labor and schooling. We use data from Burkinabe Response to Improve Girl's Chances to Succeed 2007-2008 or BRIGHT program which involves the implementation of different measures for education (mobilization campaigns, feeding programs, and so on) in 132 rural villages in Burkina Faso. Child labor is defined as hours in paid or unpaid activities and participation in labor, while schooling is defined as attendance and enrollment. We use simultaneous probability model and Tobit two stages methods to show the trade-off parents make between child labor and schooling. The results suggest that schooling is the reverse of child labor, and schools' feedings programs in rural villages favor not only participation at school, but schools' feeding programs could be good policies in addressing child labor.
\end{abstract}

Keywords: child labor; schooling; poverty 


\section{Introduction}

Since childhood remains the most important stage in human development, the researchers are interested in all the factors that can influence the human capital investment at this age.

Child labor has received a considerable attention in the economic literature, where we have a very large and well documented set of scientific works on this phenomenon. Child labor is recognized as damaging for child welfare and human development (Psacharopoulos, 1997) and it contributes to poverty trap (Baland and Robinson, 1998). Authors generally try to highlight factors that explain the participation of children, and also, factors favoring the exit of children from the labor market.

The household's economic resources are recognized as very important for several dimensions of child well-being, in developing countries. Authors generally show, that child labor is mainly a problem of poverty (Basu \& Van, 1998; Huebler, 2008; Basu and al., 2010; Koissy-Kpein, 2012a). The luxury axiom approach (derived from the works of Basu \& Van, 1998) presents, in this context, schooling as luxury goods which can only be afforded by wealthy households.

Recent studies, nevertheless, reveal the counterintuitive situation where children of wealthy households are more likely to work, and less likely to attend school, compared to children of poor households. This situation, also known as "wealth paradox" was first suggested by the studies of Bhalotra and Heady (2003). Consequently, some authors questioned about the link between poverty, child labor and schooling (Kambhampati and Rajan, 2005; Nkamleu, 2006; Basu \& al., 2010; Koissy-Kpein, 2012a). Basu and al. (2010), however suggest the possibility of an inverted $U$ link between labor and poverty and conclude that child labor remains a problem of poverty. Koissy-Kpein (2012a) shows that the link between labor and poverty depends on the definition of labor and notes that children of wealthy households have a lower probability to work outside the household, but a higher probability to work in the household farm, because of the lack of external labor force in rural areas of developing countries.

Education and compulsory schooling have been considered as major instruments to eradicate child labor. Previous studies show the availability of schools to divert children from long hours in the labor market (see, Basu, 1999). Consequently, the creation of more and better schools, and/or the schools' feeding programs, could be good public policies to eradicate the phenomenon, especially for poor households. As an example, Ravallion and Wodon (1999) conclude that a lower value of stipend compared to the mean of child wage, was enough to ensure nearly full school attendance among participants.

Child labor and schooling are presented as substitutes, or reverse (Jensen and Nielsen, 1997). However, some studies show the importance and the possibility of combining school and labor, probably due to additional incomes generates by the children participation in labor (Grootaert, 1998; Heady, 2000; Kruger and Berthelon, 2003). Indeed, according to Kruger and Berthelon (2003), additional income generated by boys' employment in Nicaragua favors their schooling. For boys in Ghana, Heady (2000) notes a positive link between schooling and labor activities. Indeed, heady finds that boys who spent less than 10 hours per week on work 
for a family member (farm or no farm activities) are more likely to attend school than those who did not work at all. However, girls who work in the family no farm activity have a lower probability to attend school. Anyway, child labor remains detrimental for the accumulation of the human capital. Indeed, studies reveal that child labor significantly reduces school performances (Rosati and Rossi, 2001; Gunnarsson et al., 2006; Heady, 2003 as an example). For Bolivia and Venezuela, Psacharopoulos (1997) notes that child labor increases the probability of a failing grade and reduces their educational attainment by one to two years. Ray and Lancaster (2005) show that the negative impact of child labor on school outcomes, is more detrimental for girls than for boys.

Our study considers two outputs for child-labor (hours in paid or unpaid activities, participation) and two outputs for schooling (attendance, enrollment). We use data from Burkinabe Response to Improve Girl's Chances to Succeed 2007-2008 to show the impact of schools feeding programs on the trade-off between child participation in labor and schooling. We consider simultaneous equations models: simultaneous probability model, Tobit two stages methods. The results suggest that child labor and schooling are negatively linked, suggesting that parents make a trade-off for their decision concerning child schooling or child labor. We also note that the availability of schools' feeding programs in the village could be good policies in addressing child labor.

The paper's next section, presents the data used for the analysis, followed by the econometric strategy for the estimations, and the results derived. Then, the last section presents the conclusion.

\section{Data and Descriptive Analysis}

Our analysis uses data collected by the Mathematica Policy research on the Burkina Faso BRIGHT school evaluation. The presentation here followed in the large part, the report of Sloan, Velyvis and Levy (2009). During 2005 to 2008, the Millennium Challenge Corporation funded a two threshold country program to increase girls' educational attainment in Burkina Faso. The program known as "Burkinabe Response to Improve Girl's Chances to Succeed" and called BRIGHT was implemented in 132 rural villages, where the girl's enrolment was lower. The program consisted in the constructions of schools and separate latrines for boys and girls, and intervention such as mobilization campaign, literacy training, take-home rations, textbooks, and so forth. Mathematica Policy research was contracted to conduct evaluation impact of the program, and they oversaw data collection from rural households and schools. The survey included 291 villages of which, 132 were participants at the BRIGHT program, and 159 were comparison villages. In each village, households with school-age girls became the sample frame, and 30 of these households, were randomly selected in each village. The sampling frame at the village level was stratified by access to beast of burden (as proxy for wealth), and three strata were identified: households that owned at least one beast of burden, households that did not own, but access to one, and households that neither owned, nor had access. From each stratum ten households were randomly selected, and the process was conducted in each village. School data was also collected using 
two techniques. For the wave 1, village elders were asked about the name of all the schools that children from the village attended. Then, three schools closest to the village center, within ten kilometers, were selected as the schools to be surveyed for that village. Finally, data were collected for more than 300 schools, and matched with children in the sample. For wave 2, household data are used as starting point, and schools currently attended by children were identified. Then, schools that were within 10 kilometers of the children's village were targeted for interview, and data were matched with the children in the sample. Only data from the matched schools are found in the dataset.

The survey proposes two questionnaires:

- A household questionnaire which contains information about household characteristics (Household's assets, construction materials and water source, demographic composition, and so forth), head's education, religion, ethnicity and age, women's participation in a literacy program, and children's participation at school, children's educational outcomes (enrollment and attendance) and labor, an interesting information about parents' perceptions of boys' and girls' education, mathematics and French assessment, administrated to all children 5 to 12 years old, and so on.

- A school questionnaire with school information and characteristics (enrollment, type of school, textbook availability, whether the school offered health and feeding programs), school personnel characteristics (teachers at school, teachers' gender, teachers' training levels, and so forth), school physical structure (number of classrooms, availability of desks and chairs, school construction materials, water supply, separate latrines and presence of pre-school), student attendance rosters, and so on.

Finally, the datasets contains information about 21773 children between 5-12 years of age, but we have completed information for only 21731 children. The sample is composed of about $47 \%$ of girls. We consider two definitions for child participation in labor.

In the survey, children were asked about participation in labor activities. The first question is "during the past week, did (name) do any kind of work for someone who is not a member of this household?" with this choice of answers "yes paid", "yes unpaid" "no". This question is followed by "since last (day of the week), about how many hours did he/she do this work for someone who is not a member of this household?" From this first set of questions, we consider a first definition of child labor as, hours in paid or unpaid activities, for someone who is not a household member (Labor1).

Children were also asked about their participation, during the past week, in collecting firewood, help with cleaning, fetching water, taking care of young siblings, help tend animals, help with farming, help with shopping, and any other family work in a business, or selling goods in the street. From these information and answers about paid or unpaid labor outside the household, we consider a dichotomous variable for participation in labor activity, during the past week (Labor2). 
Concerning schooling:

- Children were asked about school or preschool attendance during the current year. We first consider a dichotomous variable for participation at school (school1).

- Enrolled children were asked about the participation at school the next week. The question is "how many days has (name) attended school in the past 7 days?". We consider that a dichotomous variable equals to one, if the child has attended school at least one time, the past week (school2).

- Then, for the last variable, we compute an output for school attendance; output which is the ratio of days the child attended school in the past seven days, over days his school has been open in the past seven days; the minimum of school opening in the past seven days, is one day (school3).

The Table 3 in annex presents the descriptive statistics.

Concerning labor outside the household, the statistics firstly suggest that less than $6 \%$ of the children work for a non member outside the household. We also note that children, who provide paid or unpaid labor outside the household, work at mean 6 hours. While the participation in any labor activity (labor2) concerns about $75 \%$ of the sample.

Concerning schooling outputs, about $40 \%$ of the children are enrolled, $38.5 \%$ of the children attended school the previous week.

The independent variables considered for our analysis are:

- For child labor: the child's age and sex, the number of adult of more than 18 years of age, the sex of the household head, the head education, the opinion about girls' and boys' schooling, the asset based approach and principal component analysis for the household permanent income (Filmer and Pritchett, 2001), the number of beasts of burden for household wealth, the presence of a school with a feeding program in the village.

- For schooling: the child's age and sex, the proportion of children of less than 18 years of age in the household, the sex of the household head, the head education, the opinion about girls' and boys' schooling, the women's participation in literacy training, the asset based approach for the household permanent income, the number of beasts of burden for household wealth, the presence of a school with a feeding program in the village.

Less than $2 \%$ of children live in a household headed by a woman. Concerning head education, since the proportion of primary, secondary, and higher education is largely fewer, we consider a dichotomous variable equals to one, if the head has ever attended school that means, primary, secondary, higher, but also non standard curriculum. The statistics suggest that $12 \%$ of children live in the household where the head has ever participated in any program of schooling.

The survey provides information about the household's opinion concerning girls' and boys' schooling. The question is "at what age should girls/boys stop attending school?" with the proposed answers being, "girls/boys should not attend school at all" and the age limit. This 
question is particularly interesting. This kind of qualitative data misses in traditional surveys while it directly provides information on the households' preference on schooling and formal education. Parents may prefer child labor compared to schooling, if they find that learning by doing provided by child labor is more useful than formal education, especially in rural areas where children are expected to inherit from land. We consider a dummy equals to one, if the household finds that girls/boys should not attend school at all. The statistics suggests that $11 \%$ of children live in a household where the parents say that girls or boys should not attend school at all. By the way, about $30 \%$ of children live in a household where at least one woman attends literacy training. This latter component may capture household preference for formal education.

We also compute dichotomous variables for the existence of a school with schools' feeding program in the village. It appears that, $72 \%$ of children live in a village with a school with a feeding program.

We compute an index for household, wealth using principal component analysis (PCA) and asset based approach (Filmer and Pritchett, 2001). The results for PCA are presented in annex (Table 4). We then consider quintile for household wealth. Figure 1 presents the participation rate in school and labor, with household wealth. We first note an increase of school enrollment rate with household wealth. We have a very few proportion of children working outside the household, and a decrease of the participation rate outside the household with the household permanent income. Although the difference is barely perceptible, the participation rate in labor activities are lower for children of richer and the richest household, compare to children of other households.

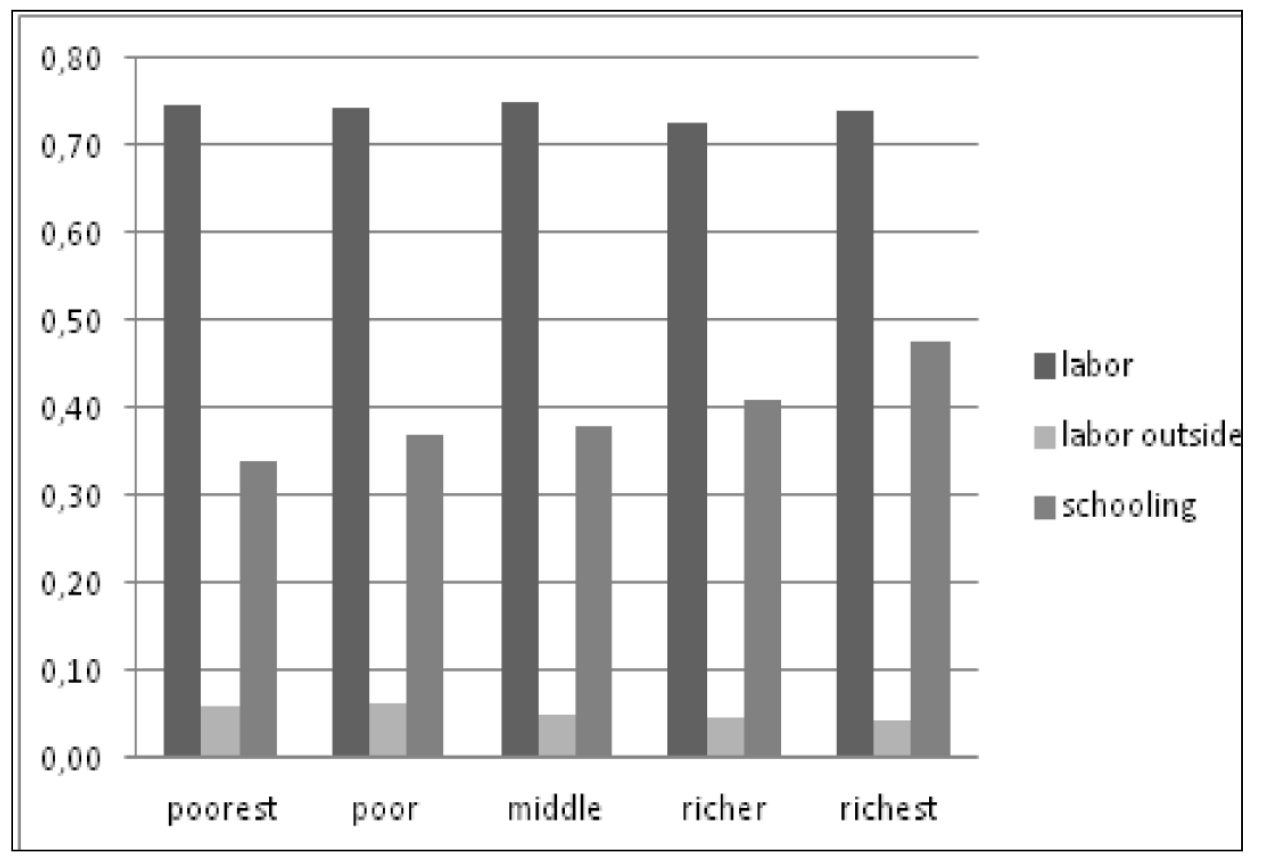

Figure 1: School Participation / Labor Participation and Household Wealth 


\section{Econometric Strategy and Results}

We consider two cases for the co-choice schooling and labor. Our discussion follows Maddala (1983).

Let's suppose $\mathrm{y}_{1}$ and $\mathrm{y}_{2}$, respectively the child's labor output (participation or hours devoted), and the child's schooling output (participation or attendance), and $X_{1}$ and $X_{2}$, matrix containing exogenous variables. The estimation strategy to be used depends on how we observe $y_{1}^{*}$ and $y_{2}^{*}$.

\subsection{The Simultaneous Probability Model for the Co-choice between School Participation and Labor Participation}

Case 1: The first case corresponds to the model 6 of Maddala $(1983,246-7)$ and refers to the

$$
\begin{aligned}
& y_{1}=1 \text { if } y_{1}^{*}>0 \\
& \text { simultaneous probability model. Suppose that: } \begin{array}{c}
y_{1}=0 \text { otherwise } \\
y_{2}=1 \text { if } y_{2}^{*}>0
\end{array} \\
& y_{2}=0 \text { otherwise }
\end{aligned}
$$

The two independent variables are dichotomous and represent, respectively, labor and school participation. The equations reduced forms are: $\begin{aligned} & y_{1}^{*}=\Pi_{1} X+v_{1} \\ & y_{2}^{*}=\Pi_{2} X+v_{2}\end{aligned}$

Where, $X$ includes all the exogenous variables in $X_{1}$ and $X_{2}$. Suppose $\operatorname{var}\left(v_{1}\right)=\sigma_{1}^{2}$ and $\operatorname{var}\left(v_{2}\right)$ $=\sigma_{2}^{2}$, since $y_{1}^{*}$ and $y_{2}^{*}$ are observed only as dichotomous variable, we can only estimate $\Pi_{1} / \sigma_{1}$ and $\Pi_{2} / \sigma_{2}$ and the estimable structural functions are:

$$
\begin{aligned}
& \hat{y}_{1}^{*}=\frac{y_{1}^{*}}{\sigma_{1}}=\gamma_{1} \frac{\sigma_{2}}{\sigma_{1}} \hat{y}_{2}^{*}+\frac{\beta_{1}^{\prime}}{\sigma_{1}} X_{1}+\frac{\varepsilon_{1}}{\sigma_{1}} \\
& \hat{y}_{2}^{*}=\frac{y_{2}^{*}}{\sigma_{1}}=\gamma_{2} \frac{\sigma_{1}}{\sigma_{2}} \hat{y}_{1}^{*}+\frac{\beta_{2}^{\prime}}{\sigma_{2}} X_{2}+\frac{\varepsilon_{2}}{\sigma_{2}} .
\end{aligned}
$$

The two stage procedure is use for the estimation of the parameters. We start by the estimation of the reduced forms by Probit ML, we derive the predicted values $\widehat{y_{1}^{*}}$ and $\widehat{y_{2}^{*}}$. Then we estimate the structural equations by Probit ML method. The estimable parameters are: $\gamma_{1} \frac{\sigma_{2}}{\sigma_{1}}$, $\gamma_{2} \frac{\sigma_{1}}{\sigma_{2}}, \frac{\beta_{1}}{\sigma_{1}}$ and $\frac{\beta_{2}}{\sigma_{2}}$. In Stata, the Biprobit is used to estimate the parameters. In this first case, child labor is defined as the participation in labor, in the past week. Child labor concerns labor for someone who is not a member of the household, help with collecting firewood, cleaning, fetching water, caring of younger siblings, tending animals, farming, shopping, selling in the street or doing any other family work. Schooling is a dichotomous variable for a child's school attendance at any time in the current year.

The table 1 presents the results of the Bivariate Probit for the co-choice between labor participation (Labor2) and school participation (school1). 
The results first suggest a significant and negative correlation between participation in labor and schooling, since the coefficient of correlation is negative and significant at $1 \%$ level. Consequently, the reason why a child does not attend school is not independent from the reason why he makes labor. From these results, school can be considered as the reverse of child labor.

The results suggest that the availability of schools with feeding programs in the village is doubly beneficial since it increases the probability of school participation and, at the same time, it decreases the probability of child participation in labor.

The negative and significant link between school and labor and the negative effect of feeding programs conduced to conclude that schooling could be a good instrument in addressing child labor.

Girls have a higher probability to make labor, but also a higher probability to attend school. This latter effect, which is somewhat counterintuitive for a developing country, could be the consequence of the BRIGHT program which was conducted to improve girls' participation at school.

The importance that the household places on education is favorable to the participation at school, since the presence of women participating in a literacy program and the head who has ever attended school have a positive and significant effect on participation at school. However, the education of the head has no effect on participation in labor.

As expected, the results reveal that children have a lower probability to attend school if parents think that boys and girls should not attend school. We also note that children have a higher probability to work if the parents think that boys should not attend school, but the effect is not significant for the opinion concerning girls' schooling.

The separated estimations according to the gender suggest that girls' participation at school increases with the negative opinion of the household concerning boys schooling, but decreases with the negative opinion concerning girls schooling. It appears here a kind of competition between girls' schooling and boys' one. By the way, the negative opinion of the household concerning boys schooling, increases the boys' labor participation, and decreases their participation at school. However, the negative opinion concerning girls' schooling increases the boys' participation at school and has a significant and negative effect on boys' labor. The results suggest that the trade-off is not only between child labor and schooling, but also between girls and boys.

Concerning the other independent variable of the estimation, the effect of the head sex is not significant, living in a household headed by a woman have no significant effect on the trade-off between child labor and schooling.

Concerning the household wealth, the results suggest an increase of schooling with the household permanent income, since from the poor households to the richest households, they have a higher probability to attend school, compared to the poorest households. By the way, children of richer, and the richest households, have a lower probability to make labor, compared to children of the poorest households. These first results suggest that child labor is a 
problem of poverty. The size of the cattle positively affects a child's participation in labor, suggesting the counterintuitive situation called "wealth paradox" by Bhalotra and Heady (2003). However, we note that the participation decreases, as the size of the cattle increases, exceeding a maximum of landholdings. So, as suggested by Basu \& al.(2010), we can talk about an inverted-U relationship, and we can conclude that a child participation in labor remains a problem of poverty. The school attendance decreases and then increases, with the size of the cattle, the decrease in the first sight could emerge from the incentive of parents, to employ their own children, or this phenomenon can also be a kind of learning by doing (Bhalotra and Heady, 2003; Koissy-Kpein, 2012a). However, wealthy household would have the possibility to hire external labor and make their children go to school.

Then, the household demographic composition suggests that the presence of children in the household decreases the probability of school participation, while the presence of adults has no significant effect on the labor activity.

Table 1: Bivariate Probit for the Co-choice between Labor and Schooling

\begin{tabular}{|c|c|c|c|}
\hline VARIABLES & $\begin{array}{c}\text { (1) } \\
\text { Child labor }\end{array}$ & $\begin{array}{c}(2) \\
\text { schooling }\end{array}$ & $\begin{array}{c}\text { (3) } \\
\text { athrho }\end{array}$ \\
\hline Female & $\begin{array}{c}0.228 * * * \\
(0.0194)\end{array}$ & $\begin{array}{c}0.0333^{*} \\
(0.0188)\end{array}$ & \\
\hline Age & $\begin{array}{c}0.582 * * * \\
(0.0334)\end{array}$ & $\begin{array}{l}1.834 * * * \\
(0.0354)\end{array}$ & \\
\hline $\mathrm{Age}^{2}$ & $\begin{array}{c}-0.0243 * * * \\
(0.00200)\end{array}$ & $\begin{array}{c}-0.101 * * * \\
(0.00206)\end{array}$ & \\
\hline Proportion of children in the $\mathrm{HH}$ & & $\begin{array}{c}-0.336^{* * *} \\
(0.0629)\end{array}$ & \\
\hline Female HH headed & $\begin{array}{c}-0.0751 \\
(0.0738)\end{array}$ & $\begin{array}{c}0.0137 \\
(0.0708)\end{array}$ & \\
\hline Head ever attended school & $\begin{array}{c}0.0298 \\
(0.0299)\end{array}$ & $\begin{array}{c}0.224 * * * \\
(0.0293)\end{array}$ & \\
\hline Boys should not attend school & $\begin{array}{c}0.225 * * * \\
(0.0408)\end{array}$ & $\begin{array}{c}-0.511 * * * \\
(0.0446)\end{array}$ & \\
\hline Girls should not attend school & $\begin{array}{c}-0.0527 \\
(0.0383)\end{array}$ & $\begin{array}{c}-0.353^{* * *} \\
(0.0418)\end{array}$ & \\
\hline Participation in women literacy training & & $\begin{array}{c}0.183 * * * \\
(0.0205)\end{array}$ & \\
\hline Poor $\mathrm{HH}$ & $\begin{array}{l}-0.0410 \\
(0.0275)\end{array}$ & $\begin{array}{c}0.0739 * * * \\
(0.0272)\end{array}$ & \\
\hline Middle HH & $\begin{array}{c}-0.0369 \\
(0.0319)\end{array}$ & $\begin{array}{l}0.112 * * * \\
(0.0312)\end{array}$ & \\
\hline Richer HH & $\begin{array}{c}-0.138 * * * \\
(0.0326)\end{array}$ & $\begin{array}{c}0.228 * * * \\
(0.0316)\end{array}$ & \\
\hline Richest HH & $\begin{array}{c}-0.0705^{* *} \\
(0.0308)\end{array}$ & $\begin{array}{c}0.352 * * * \\
(0.0296)\end{array}$ & \\
\hline Cattle & $\begin{array}{c}0.0130 * * * \\
(0.00185)\end{array}$ & $\begin{array}{c}-0.0183 * * * \\
(0.00176)\end{array}$ & \\
\hline Cattle $^{2}$ & $\begin{array}{c}-0.0121 * * * \\
(0.00264)\end{array}$ & $\begin{array}{c}0.0160^{* * *} * \\
(0.00253)\end{array}$ & \\
\hline Feeding program for school in the village & $\begin{array}{c}-0.123 * * * \\
(0.0218)\end{array}$ & $\begin{array}{c}0.546^{* * * *} \\
(0.0222)\end{array}$ & \\
\hline Adults in the $\mathrm{HH}$ & $\begin{array}{c}-0.00308 \\
(0.00273)\end{array}$ & & \\
\hline Constant & $\begin{array}{c}-2.310 * * * \\
(0.133)\end{array}$ & $\begin{array}{c}-8.309 * * * \\
(0.153)\end{array}$ & $\begin{array}{c}-0.238^{* * *} \\
(0.0136)\end{array}$ \\
\hline Observations & 21731 & 21731 & 21731 \\
\hline
\end{tabular}


3.2 The Tobit two Stage Methods for the Co-choice between Hours in Labor Market and School Attendance

Case 2: The second case corresponds to the $4^{\text {th }}$ model of Maddala (1983, 245-6), Tobit two

stage methods: $\begin{aligned} & y_{1}=y_{1}^{*} \text { if } y_{1}^{*}>0 \\ & y_{1}=0 \text { otherwise } \\ & y_{2}=y_{2}^{*} \text { if } y_{2}^{*}>0 \\ & y_{2}=0 \text { otherwise }\end{aligned}$

In this case, the two dependant variables are censored, and they represent the days at school for enrolled children (school3) and the hours in labor activity for children who participate (labor1).

The Mvtobit model, in Stata inspired by the Mvprobit model Cappelari and Jenkins, allows the estimation for the two censored dependent variables (Barslund, 2009). Mvtobit estimates M-equation Tobit models, by the method of maximum simulated likelihood (MSL). The command uses the Geweke-Hajivassiliou-Keane (GHK) simulator. Under standard conditions, the MSL estimator is consistent as the number of observations and the number of draws tends to infinity, and is asymptotically equivalent to the true maximum likelihood estimator as the ratio of the square root of the sample size to the number of draws tends to zero. Thus, other things equal, the more draws there are, the better accurate the results. In practice, however, it has been observed that a relatively small number of draws may work well for 'smooth' likelihoods in the sense that the change in estimates as the number of draws is increased is negligible. It is the responsibility of the user to check that this is the case. Simulation variance may be reduced using antithetic draws in addition to the pseudo-random uniform variates used in the calculation of the simulated likelihood. The antithetic draws for a vector of pseudo-random uniform draws, z, are 1-z. We apply the rule-of-thumb that the number of draws made by the GHK estimator for each simulation is the square toot of the number of observations (see Cappellari and Jenkins, 2003).

Table 2 presents the results of the Mvtobit for the hours spent in paid or unpaid activities outside the household for a non member the past seven days and the school attendance. School attendance is the ratio of days the child attended school in the past seven days and days his school been open in the past seven days (the minimum of school opening in the past seven days is one day).

The coefficient of correlation among school attendance and time spent in paid or unpaid activities outside the household is significant and negative, suggesting a negative link between the two activities. As in the previous case, schooling can be defined as a good way to get the children out of the labor market. The presence of a school with feeding programs have a positive and significant effect on school attendance, but also a significant and positive effect on hours spent in the labor market. The results in the Table 6, by sex, suggest that this positive and significant effect appears only for boys' participation in the labor market, while the effect is no significant for girls. So, feeding programs could be good policies in addressing child participation in labor, but could have perverse effect on time spent for some of the children in labor outside the household for non member. May be that parents will have an incentive to increase the time spent on the labor market by boys receiving food at school, since these 
children might be more able to work. So, the feeding programs would help to increase school participation but should be completed by other measures to avoid perverse consequences for children.

The results suggest that girls spend less time in labor outside the household for a non member compared to boys. However, from the previous case, girls have a higher probability to make labor. This difference comes from the definition of labor, participation or hours, but also the composition of child labor. Indeed, in the previous case, child labor is defined as participation in all the activities including labor outside the household, household chores, labor in the household farm and so on. Girls' labor activity may consist mainly on household chores, and this could explain their lower time spent outside the household. We also note that girls spend more time at school compare to boys. As in the previous case, this can be the direct consequence of the BRIGHT project.

As in the previous case, the proportion of children among the household member is a decreasing component of time at school. However, the number of adult in the household decreases the time spent in labor activities outside the household, while this component is not significant for participation in labor (case 1). This suggests that the presence of other adults in the household is favorable to the eradication of child's participation in labor only through time spent in labor outside the household. This is probably due to the adults contribution to the household income, reinforcing the assumption that child labor is a problem of poverty.

The results also show that children of household headed by a woman spend less time in labor outside the household while the component is not significant in the previous case. This component is also no significant on school attendance. Previous studies, however suggest that since household headed by woman are mainly among the poorest, children of these households have a higher probability to make labor compared to the others. Indeed, For Bolivia, Psacharopoulos (1997) found that the probability of a working child is higher in female-headed households. Koissy-Kpein (2012b) note for Mali that having a female household head increases the probability of school participation, but also increases the probability of participation in labor outside the household for a non member, especially for boys. Ray (2000), for Peru and Pakistan, show that these households are more dependent on children's earnings and child labor than are male-headed households.

Education in the household and perception of the importance of education play an important role on school attendance. Indeed, the head education positively affects time spent in school. In Table 6, it appears that head education has a negative and significant effect on time spent by boys in the labor market, while no significant effect appears for time spent by girls. We also note that the participation in a women's literacy program has a positive and significant effect on school attendance.

If the household does not find any interest on girls' or boys' education, children will spend less time in school. If the household does not find any interest on boys' education, children will spend more time in the labor market. Here, we find difference according to the gender of the offspring. Indeed, the household does not find any interest on girls' education, girls will spend less time at school, and boys will spend more time at school. However, if the household does 
not find any interest on boys' education, boys will spend less time at school and girls will spend more time at school.

Concerning child labor, if the household does not find any interest on girls' education, boys will spend less time on the labor market. But, if the household does not find any interest on boys' education, girls will spend less time on the labor market and boys will spend more time in the labor market.

We still find that competition between girls and boys. The results show how gender, preference and opinion interact, which reveals the complexity of the decision-making process in the household. Households' opinion concerning formal education is probably link to the expected return of this education for the household. They probably value the choice child labor as an informal way for education. In this sense, it will be challenging to eradicate child labor only through educational policies.

The household wealth remains an important component of participation at school and times in the labor market. Indeed, children of the middle, richer and richest households spent less time in the labor market compared to children of the poorest household. By the way, school attendance also increases with the household wealth.

Then, concerning the size of the cattle, we have the same results that in the previous case. Suggesting that, children of the wealthy household in cattle have a lower probability to spend time in labor outside the household and a higher probability to spend time in school.

Table 2: Mvtobit for Hours in Labor Activity outside the Household for a Non Member and School Attendance

\begin{tabular}{|c|c|c|c|c|c|}
\hline VARIABLES & $\begin{array}{c}(1) \\
\text { Hours in labor }\end{array}$ & $\begin{array}{c}(2) \\
\text { School attendance }\end{array}$ & $\begin{array}{c}\text { (3) } \\
\text { lnsigma1 }\end{array}$ & $\begin{array}{c}(4) \\
\text { Insigma2 }\end{array}$ & $\begin{array}{c}(5) \\
\text { atrho12 }\end{array}$ \\
\hline Female & $\begin{array}{l}-0.647 * \\
(0.363)\end{array}$ & $\begin{array}{c}0.0360^{* *} \\
(0.0150)\end{array}$ & & & \\
\hline Age & $\begin{array}{c}2.241 * * * \\
(0.659)\end{array}$ & $\begin{array}{l}1.608 * * * \\
(0.0280)\end{array}$ & & & \\
\hline $\mathrm{Age}^{2}$ & $\begin{array}{l}-0.0410 \\
(0.0376)\end{array}$ & $\begin{array}{c}-0.0887 * * * \\
(0.00164)\end{array}$ & & & \\
\hline Proportion of children in the $\mathrm{HH}$ & & $\begin{array}{l}-0.302 * * * \\
(0.0499)\end{array}$ & & & \\
\hline Female headed $\mathrm{HH}$ & $\begin{array}{c}-6.702 * * * \\
(1.910)\end{array}$ & $\begin{array}{c}0.0298 \\
(0.0583)\end{array}$ & & & \\
\hline Head ever attend school & $\begin{array}{l}-0.639 \\
(0.573)\end{array}$ & $\begin{array}{l}0.160 * * * \\
(0.0215)\end{array}$ & & & \\
\hline Boys should not attend school & $\begin{array}{l}1.121^{*} \\
(0.659)\end{array}$ & $\begin{array}{l}-0.469 * * * \\
(0.0392)\end{array}$ & & & \\
\hline Girls should not attend school & $\begin{array}{l}-0.747 \\
(0.643)\end{array}$ & $\begin{array}{l}-0.344 * * * \\
(0.0364)\end{array}$ & & & \\
\hline $\begin{array}{l}\text { Participation in women literacy } \\
\text { training }\end{array}$ & & $\begin{array}{l}0.138 * * * \\
(0.0158)\end{array}$ & & & \\
\hline Poor $\mathrm{HH}$ & $\begin{array}{c}0.00639 \\
(0.496)\end{array}$ & $\begin{array}{l}0.0732 * * * \\
(0.0226)\end{array}$ & & & \\
\hline Middle $\mathrm{HH}$ & $\begin{array}{l}-1.617 * * * \\
(0.615)\end{array}$ & $\begin{array}{l}0.107 * * * \\
(0.0258)\end{array}$ & & & \\
\hline Richer HH & $\begin{array}{c}-2.013 * * * \\
(0.627)\end{array}$ & $\begin{array}{l}0.195 * * * \\
(0.0255)\end{array}$ & & & \\
\hline Richest HH & $\begin{array}{c}-2.290 * * * \\
(0.604)\end{array}$ & $\begin{array}{l}0.291 * * * \\
(0.0234)\end{array}$ & & & \\
\hline Cattle & $0.335 * * *$ & $-0.0144 * * *$ & & & \\
\hline
\end{tabular}




\section{$\underline{\Lambda \text { Macrothink }}$}

\begin{tabular}{|c|c|c|c|c|c|}
\hline & $(0.0534)$ & $(0.00136)$ & & & \\
\hline Cattle $^{2}$ & $-0.730 * * *$ & $0.0124 * * *$ & & & \\
\hline \multirow{3}{*}{$\begin{array}{l}\text { Feeding program for school in the } \\
\text { village }\end{array}$} & $(0.143)$ & $(0.00166)$ & & & \\
\hline & $1.128 * * *$ & $0.452 * * *$ & & & \\
\hline & $(0.414)$ & $(0.0191)$ & & & \\
\hline Adults in the household & $\begin{array}{l}-0.307 * * * \\
(0.0683)\end{array}$ & & & & \\
\hline Constant & $\begin{array}{l}-35.68 * * * \\
(2.917)\end{array}$ & $\begin{array}{l}-7.178 * * * \\
(0.121)\end{array}$ & $\begin{array}{l}2.549 * * * \\
(0.0218)\end{array}$ & $\begin{array}{c}-0.0812 * * * \\
(0.00662)\end{array}$ & $\begin{array}{c}-0.172 * * * \\
(0.0168)\end{array}$ \\
\hline Observations & 21731 & 21731 & 21731 & 21731 & 21731 \\
\hline
\end{tabular}

Robust standard errors in parentheses

$* * * \mathrm{p}<0.01, * * \mathrm{p}<0.05, * \mathrm{p}<0.1$

\section{Conclusion}

The focus in this work concerns the effect of schools' feeding programs on the trade-off parents make between school participation and child labor. We use data from the Burkina Faso BRIGHT school evaluation, implemented for the evaluation of the BRIGHT program. We consider a Bivariate Probit estimation for the co-choice between school participation and labor participation, and then, a Tobit two stage methods for the co-choice between hours in labor market and school attendance.

It appears from our analysis that schooling and schools' feeding programs favor the withdrawal of children from the labor market. However, schools' feeding programs could have an unexpected effect on time spent by children, and boys especially, on the labor market. Consequently, it would be interesting to consider additional measures to address child labor.

Child labor and schooling are negatively linked, suggesting that parents make a trade-off for their decision concerning child schooling or child labor. This trade-off is mainly influenced by the household's wealth, and constrained by poverty. A very few difference emerges from factors affecting outputs according to the output's definition used or the methodology used. Suggesting that interpretation for the determinants of child labor or schooling should be made carefully. As an example, from the bivariate Probit estimation, we note that girls have a higher probability to make labor compared to boys, but from the bivariate Tobit estimation, it appears that girls spent less time in labor outside the household compared to boys. This difference could be the fact of the gender definition or roles and tasks, since girls have a higher probability to make household chores. Another example comes from the gender of the household head. Children from household headed by a woman spent less time in labor outside the household. However, we do not find any difference between children from household headed by a woman and the other households, from the bivariate Probit estimation for the co-choice between participation on labor and participation at school.

\section{Acknowledgement}

The present paper is part of the post-doctoral project "Gender bias in schooling decision: the impact of household production and parents' bargaining power." The project was supported by the National Research Fund, Luxembourg, and cofounded under the Marie Curie Actions of the European Commission (FP7-COFUND). 
This work is based on freely accessible data from BRIGHT program funded by the Millenium Challenge Corporation, a US government agency. http://catalog.data.gov/dataset/burkina-faso-bright-evaluation-data

\section{References}

Baland, J.-M., \& J. A. Robinson (1998). A Model of Child Labor. Retrieved from http://ideas.repec.org/p/fth/socaec/9803.html

Barslund, M. C. (2009). MVTOBIT: Stata module to calculate multivariate tobit models by simulated maximum likelihood (SML), In (Editor Ed.)^Eds.), Book MVTOBIT: Stata module to calculate multivariate tobit models by simulated maximum likelihood (SML), City.

Basu, K. (1999). Child Labor: Cause, Consequence, and Cure, with Remarks on International Labor Standards. Journal of Economic Literature, 37(3), 1083-1119. http://dx.doi.org/10.1257/jel.37.3.1083

Basu, K., S. Das \& B. Dutta. (2010). Child labor and household wealth: Theory and empirical evidence of an inverted-U. Journal of Development Economics, 91(1), 8-14. http://dx.doi.org/10.1016/j.jdeveco.2009.01.006

Basu, K., \& P. H. Van (1998). The Economics of Child Labor. The American Economic Review, 88(3), 412-427.

Bhalotra, S., \& C. Heady. (2003). Child Farm Labor: The Wealth Paradox. THE WORLD BANK ECONOMIC REVIEW, 17(2), 197-227. http://dx.doi.org/10.1093/wber/lhg017

Cappellari, L., \& S. Jenkins. (2003). Multivariate probit regression using simulated maximum likelihood. The Stata Journal, 3(3), 278-294.

Filmer, D., \& L. Pritchett. (2001). Estimating Wealth Effects Without Expenditure Data-Or Tears: An Application to Educational Enrollments in States of India. Demography, 38(1), 115-132.

Grootaert, C. (1998). Child Labor in Côte d'Ivoire: Incidence and Determinants. World Bank Policy Research Working Paper No. 569204. World Bank. Retrieved from http://ssrn.com/paper=569204

Heady, C. (2000). What Is the Effect of Child Labour on Learning Achievement? Evidence from Ghana. UNICEF Innocenti Research Centre. Retrieved from http://www.unicef-icdc.org

Huebler, F. (2008). Child labour and school attendance: Evidence from MICS and DHS surveys, UNICEF. Retrieved from http://www.childinfo.org/labour_publications.html

Jensen, P., \& H. S. Nielsen. (1997). Child labour or school attendance? Evidence from Zambia. Journal of Population Economics, 10(4), 407-424. 
http://dx.doi.org/10.1007/s001480050051

Koissy-Kpein, S. A. (2012a). Child labor, schooling and household wealth in African rural area: luxury axiom or wealth paradox. CEPS/INSTEAD.

Koissy-Kpein, S. A. (2012b). Gender and competition between economic and non economic labor and schooling: evidence from EPAM MALI. African Development Review, 24(1), 1-17. http://dx.doi.org/10.1111/j.1467-8268.2011.00308.x

Kruger, D., \& M. Berthelon. (2003). How Households Economic Opportunity Affect Child Labor and Schooling in Nicaragua: Differential Effects by Gender. The Georgetown Public Policy Review, 9, 1-16.

Maddala, G. S. (1983). Limited Dependent and Qualitative Variables in Econometrics. Cambridge University Press. http://dx.doi.org/10.1017/CBO9780511810176

Psacharopoulos, G. (1997). Child labor versus educational attainment Some evidence from Latin America. Journal of Population Economics, 10(4), 377-386. http://dx.doi.org/10.1007/s001480050049

Ravallion, M., \& Q. Wodon (1999). Does Child Labor Displace Schooling? Evidence on Behavioral Responses to an Enrollment Subsidy. World Bank. http://dx.doi.org/10.1596/1813-9450-2116

Ray, R. (2000). Analysis of child labour in Peru and Pakistan: A comparative study. Journal of Population Economics, 13(1), 3-19. http://dx.doi.org/10.1007/s001480050119

Ray, R., \& G. Lancaster (2005). The impact of children's work on schooling: Multi-country evidence. International Labour Review, 144, 189-210. http://dx.doi.org/10.1111/j.1564-913X.2005.tb00565.x

Sloan, M., K. Velyvis \& D. Levy. (2009). Burkina Faso's BRIGHT School Evaluation: Household and School Survey User's Manual. Final Report Washington Mathematica Policy Research, INC. 


\section{Appendix}

Table 3: Summary Statistics

\begin{tabular}{llllll}
\hline variable & mean & sd & min & max & $\mathrm{N}$ \\
\hline Labor participation & .7419815 & .4375543 & 0 & 1 & 21731 \\
Hours in labor activities & .4303833 & 2.020611 & 0 & 21 & 16124 \\
School enrollment & .3919746 & .4882023 & 0 & 1 & 21731 \\
School attendance & .9768314 & .1404376 & 0 & 1 & 8518 \\
Girls & .4687773 & .4990357 & 0 & 1 & 21731 \\
Age & 8.121117 & 2.284899 & 5 & 12 & 21731 \\
Number of adults in the HH & 4.842253 & 3.589467 & 0 & 36 & 21731 \\
Proportion of children in the household & .560388 & .1498265 & 0 & 1 & 21731 \\
Female household head & .0174405 & .1309089 & 0 & 1 & 21731 \\
Head ever attend school & .1171138 & .3215632 & 0 & 1 & 21731 \\
Boys should not attend school & .1076803 & .3099833 & 0 & 1 & 21731 \\
Girls should not attend school & .1179881 & .3226015 & 0 & 1 & 21731 \\
Participation in a women literacy program & .2880677 & .4528732 & 0 & 1 & 21731 \\
Poor HH & .260549 & .438945 & 0 & 1 & 21731 \\
Middle HH & .152547 & .359559 & 0 & 1 & 21731 \\
Richer HH & .154388 & .361328 & 0 & 1 & 21731 \\
Richest HH & .20335 & .4025 & 0 & 1 & 21731 \\
Cattle & 5.489439 & 9.887448 & 0 & 150 & 21731 \\
Feeding program for school in the village & .7225162 & .4477675 & 0 & 1 & 21731 \\
\hline
\end{tabular}

The table presents the descriptive statistics (mean, standard deviation, minimum value, maximum value, observations) of variable used in the estimation.

Table 4: Results from Principal Component Analysis for Household Wealth

\begin{tabular}{llllr}
\hline variable & mean & sd & factor score & N \\
\hline modern material for Floor & .0497225 & .2173838 & 0.2999 & \\
modern material for roof & .1143262 & .3182258 & 0.3271 & 8467 \\
radios & .5620645 & .4961623 & 0.2949 & 8467 \\
GSM & .1404275 & .3474506 & 0.4943 & 8467 \\
watches & .1404275 & .3474506 & 0.4943 & 8467 \\
velo & .8596906 & .3473283 & 0.1856 & \\
moto & .2109366 & .4079975 & 0.3496 & \multicolumn{2}{c}{8467} \\
animal cart & .4431322 & .4967849 & 0.2661 & \multicolumn{2}{c}{8467} \\
Eigenvalue & & & & 2.72526 \\
Proportion & & & & 0.3407 \\
\hline
\end{tabular}


Table 5: Bivariate probit for the co-choice between labor and schooling for girls and boys

\begin{tabular}{|c|c|c|c|c|c|c|}
\hline \multirow[b]{2}{*}{ VARIABLES } & \multicolumn{3}{|c|}{ Girls } & \multicolumn{3}{|c|}{ Boys } \\
\hline & Child labor & Schooling & athrho & Child labor & Schooling & athrho \\
\hline \multirow[t]{2}{*}{ Age } & $0.728 * * *$ & $1.789 * * *$ & & $0.470 * * *$ & $1.874 * * *$ & \\
\hline & $(0.0508)$ & $(0.0521)$ & & $(0.0447)$ & $(0.0503)$ & \\
\hline \multirow[t]{2}{*}{ Age $^{2}$} & $-0.0322 * * *$ & $-0.0992 * * *$ & & $-0.0183 * * *$ & $-0.103 * * *$ & \\
\hline & $(0.00307)$ & $(0.00306)$ & & $(0.00265)$ & $(0.00290)$ & \\
\hline \multirow[t]{2}{*}{ Proportion of children in the $\mathrm{HH}$} & & $-0.242 * *$ & & & $-0.325 * * *$ & \\
\hline & & $(0.0951)$ & & & $(0.0866)$ & \\
\hline \multirow[t]{2}{*}{ HH headed by a woman } & -0.103 & -0.0788 & & -0.0466 & 0.125 & \\
\hline & $(0.0997)$ & $(0.0957)$ & & $(0.109)$ & $(0.107)$ & \\
\hline \multirow[t]{2}{*}{ Head ever attended school } & 0.0730 & $0.212 * * *$ & & -0.00561 & $0.249 * * *$ & \\
\hline & $(0.0448)$ & $(0.0417)$ & & $(0.0405)$ & $(0.0419)$ & \\
\hline \multirow[t]{2}{*}{ Boys should not attend school } & 0.0847 & $0.515^{* * *}$ & & $0.365 * * *$ & $-1.737 * * *$ & \\
\hline & $(0.0590)$ & $(0.0652)$ & & $(0.0581)$ & $(0.0916)$ & \\
\hline \multirow[t]{2}{*}{ Girls should not attend school } & 0.0117 & $-1.763 * * *$ & & $-0.107 * *$ & $0.424 * * *$ & \\
\hline & $(0.0628)$ & $(0.102)$ & & $(0.0490)$ & $(0.0556)$ & \\
\hline \multirow[t]{2}{*}{ Participation in women literacy training } & & $0.273^{* * *}$ & & & $0.123 * * *$ & \\
\hline & & $(0.0300)$ & & & $(0.0287)$ & \\
\hline \multirow[t]{2}{*}{ Poor HH } & -0.0286 & $0.0846^{* *}$ & & -0.0528 & $0.0830^{* *}$ & \\
\hline & $(0.0419)$ & $(0.0403)$ & & $(0.0366)$ & $(0.0381)$ & \\
\hline \multirow[t]{2}{*}{ Middle HH } & 0.0216 & 0.0655 & & $-0.0818^{*}$ & $0.136 * * *$ & \\
\hline & $(0.0488)$ & $(0.0465)$ & & $(0.0425)$ & $(0.0433)$ & \\
\hline \multirow[t]{2}{*}{ Richer HH } & -0.0783 & $0.203 * * *$ & & $-0.183 * * *$ & $0.264 * * *$ & \\
\hline & $(0.0494)$ & $(0.0470)$ & & $(0.0434)$ & $(0.0440)$ & \\
\hline \multirow[t]{2}{*}{ Richest HH } & $-0.0978 * *$ & $0.299 * * *$ & & -0.0507 & $0.398 * * *$ & \\
\hline & $(0.0460)$ & $(0.0439)$ & & $(0.0414)$ & $(0.0411)$ & \\
\hline \multirow[t]{2}{*}{ Cattle } & $0.0110 * * *$ & $-0.0161 * * *$ & & $0.0146^{* * *}$ & $-0.0190 * * *$ & \\
\hline & $(0.00280)$ & $(0.00255)$ & & $(0.00242)$ & $(0.00247)$ & \\
\hline \multirow[t]{2}{*}{ Cattle $^{2}$} & $-0.0113 * * *$ & $0.0131 * * *$ & & $-0.0125 * * *$ & $0.0176^{* * *}$ & \\
\hline & $(0.00404)$ & $(0.00355)$ & & $(0.00336)$ & $(0.00358)$ & \\
\hline \multirow[t]{2}{*}{ Feeding program for school in the village } & $-0.154 * * *$ & $0.572 * * *$ & & $-0.0943 * * *$ & $0.473 * * *$ & \\
\hline & $(0.0338)$ & $(0.0335)$ & & $(0.0288)$ & $(0.0306)$ & \\
\hline \multirow[t]{2}{*}{ Number of adults in the $\mathrm{HH}$} & -0.00472 & & & -0.00174 & & \\
\hline & $(0.00407)$ & & & $(0.00370)$ & & \\
\hline \multirow[t]{2}{*}{ Constant } & $-2.664 * * *$ & $-8.171 * * *$ & $-0.187 * * *$ & $-1.861 * * *$ & $-8.495 * * *$ & $-0.271 * * *$ \\
\hline & $(0.200)$ & $(0.224)$ & $(0.0208)$ & $(0.179)$ & $(0.218)$ & $(0.0185)$ \\
\hline Observations & 10187 & 10187 & 10187 & 11544 & 11544 & 11544 \\
\hline
\end{tabular}

Robust standard errors in parentheses

${ }^{* * *} \mathrm{p}<0.01,{ }^{* *} \mathrm{p}<0.05,{ }^{*} \mathrm{p}<0.1$ 
Table 6: MvTobit for hours in labor activity outside the household for a non member and school attendance for girls and boys

\begin{tabular}{|c|c|c|c|c|c|c|c|c|c|c|}
\hline \multirow[b]{2}{*}{ variable } & \multicolumn{5}{|c|}{ Girls } & \multicolumn{5}{|c|}{ Boys } \\
\hline & Hours in & School & Insigma1 & Insigma2 & atrho12 & Hours in & School & lnsigma1 & Insigma2 & atrho12 \\
\hline \multirow[t]{2}{*}{ Age } & $4.626^{* * *}$ & $1.479 * * *$ & & & & 0.389 & $1.642 * * *$ & & & \\
\hline & $(0.911)$ & $(0.0399)$ & & & & $(0.957)$ & $(0.0391)$ & & & \\
\hline \multirow[t]{2}{*}{$\mathrm{Age}^{2}$} & $-0.200 * *$ & $-0.0818 * * *$ & & & & 0.0818 & $-0.0900 * *$ & & & \\
\hline & $(0.0523)$ & $(0.00236)$ & & & & $(0.0543)$ & $(0.00227)$ & & & \\
\hline \multirow[t]{2}{*}{ Children } & & $-0.189 * * *$ & & & & & $-0.309 * * *$ & & & \\
\hline & & $(0.0721)$ & & & & & $(0.0674)$ & & & \\
\hline \multirow[t]{2}{*}{ F. head } & $-4.407 * *$ & -0.0525 & & & & $-10.05 * *$ & 0.122 & & & \\
\hline & $(2.063)$ & $(0.0779)$ & & & & $(3.802)$ & $(0.0823)$ & & & \\
\hline \multirow[t]{2}{*}{ Head } & 0.615 & $0.146^{* * *}$ & & & & $-2.048 * *$ & $0.175 * * *$ & & & \\
\hline & $(0.707)$ & $(0.0294)$ & & & & $(0.909)$ & $(0.0301)$ & & & \\
\hline \multirow[t]{2}{*}{ Boys } & $-2.681 * *$ & $0.338 * * *$ & & & & $4.717 * * *$ & $-1.649 * * *$ & & & \\
\hline & $(0.907)$ & $(0.0405)$ & & & & $(0.966)$ & $(0.0862)$ & & & \\
\hline \multirow[t]{2}{*}{ Girls } & 0.543 & $-1.511 * * *$ & & & & $-2.166^{* *}$ & $0.278 * * *$ & & & \\
\hline & $(0.995)$ & $(0.0835)$ & & & & $(0.892)$ & $(0.0385)$ & & & \\
\hline \multirow[t]{2}{*}{ women } & & $0.193 * * *$ & & & & & $0.101 * * *$ & & & \\
\hline & & $(0.0219)$ & & & & & $(0.0222)$ & & & \\
\hline \multirow[t]{2}{*}{ Poor HH } & -0.784 & $0.0853^{* * *}$ & & & & 0.635 & $0.0743 * *$ & & & \\
\hline & $(0.678)$ & $(0.0317)$ & & & & $(0.709)$ & $(0.0311)$ & & & \\
\hline \multirow[t]{2}{*}{ Middle } & $-1.524^{*}$ & $0.0667 *$ & & & & $-1.694^{*}$ & $0.121 * * *$ & & & \\
\hline & $(0.823)$ & $(0.0365)$ & & & & $(0.895)$ & $(0.0349)$ & & & \\
\hline \multirow[t]{2}{*}{ Richer } & $-2.468 * *$ & $0.178 * * *$ & & & & $-1.764 * *$ & $0.208 * * *$ & & & \\
\hline & $(0.882)$ & $(0.0360)$ & & & & $(0.881)$ & $(0.0348)$ & & & \\
\hline \multirow[t]{2}{*}{ Richest } & $-1.845 * *$ & $0.247 * * *$ & & & & $-2.830 * *$ & $0.311 * * *$ & & & \\
\hline & $(0.796)$ & $(0.0329)$ & & & & $(0.889)$ & $(0.0319)$ & & & \\
\hline \multirow[t]{2}{*}{ Cattle } & $0.392 * * *$ & $-0.0120 * * *$ & & & & $0.287 * * *$ & $-0.0143 * *$ & & & \\
\hline & $(0.0761)$ & $(0.00190)$ & & & & $(0.0727)$ & $(0.00189)$ & & & \\
\hline \multirow[t]{2}{*}{ Cattle $^{2}$} & $-0.939 * *$ & $0.00968 * *$ & & & & $-0.577 * *$ & $0.0132 * * *$ & & & \\
\hline & $(0.220)$ & $(0.00228)$ & & & & $(0.183)$ & $(0.00231)$ & & & \\
\hline \multirow[t]{2}{*}{ Feeding } & 0.359 & $0.455^{* * *}$ & & & & $1.822 * * *$ & $0.378 * * *$ & & & \\
\hline & $(0.559)$ & $(0.0279)$ & & & & $(0.595)$ & $(0.0259)$ & & & \\
\hline \multirow[t]{2}{*}{$\mathrm{n}$ adults } & $-0.301 * *$ & & & & & $-0.320 * *$ & & & & \\
\hline & $(0.0885)$ & & & & & $(0.0989)$ & & & & \\
\hline \multirow[t]{2}{*}{ Constant } & $-41.41 * *$ & $-6.645^{* * *}$ & $2.446^{* *}$ & $-0.121 * *$ & $-0.131 * *$ & $-31.43 * *$ & $-7.315^{* * *}$ & $2.609 * *$ & $-0.0985^{* *}$ & $-0.184 * *$ \\
\hline & $(4.133)$ & $(0.171)$ & $(0.0349)$ & $(0.00988)$ & $(0.0245)$ & $(4.147)$ & $(0.171)$ & $(0.0280)$ & $(0.00949)$ & $(0.0242)$ \\
\hline $\mathrm{n}$ & 10187 & 10187 & 10187 & 10187 & 10187 & 11544 & 11544 & 11544 & 11544 & 11544 \\
\hline
\end{tabular}




\section{Copyright Disclaimer}

Copyright reserved by the author(s).

This article is an open-access article distributed under the terms and conditions of the Creative Commons Attribution license (http://creativecommons.org/licenses/by/3.0/). 